\title{
Labour Migration from Indonesia to South Korea: Challenges in Maximizing Potentials
}

\author{
Sylvia Yazid \\ International Relations Department, Faculty of Social and Poltical Science \\ Parahyangan Catholic University, Jl. Ciumbuleuit No. 94, Bandung, West Java 40141 \\ s_yazid@unpar.ac.id \\ Submitted: 20 June 2017, Accepted: 2 September 2017
}

\begin{abstract}
Abstrak
Analisa tentang mengapa seseorang bermigrasi untuk bekerja di negara lain umumnya dilakukan melalui pencarian dan pendeskripsian faktor-faktor "push" dan "pull", di mana pendapatan rendah dan pengangguran yang tinggi menjadi faktor pendorong dan pendapatan tinggi dan pengangguran yang rendah menjadi faktor penarik. Ini dapat digunakan untuk menjelaskan alasan umum bagi migrasi tenaga kerja yang bersifat sementara namun tidak cukup untuk menjelaskan lebih lanjut mengapa seseorang memutuskan bermigrasi ke suatu negara dan bukan ke negara lainnya. Inilah yang dihadapi Indonesia dan Korea Selatan. Walaupun masih banyak orang yang mencari pekerjaan di Indonesia dan Korea Selatan masih membutuhkan pekerja asing, jumlah orang Indonesia yang bekerja di kategorikan kecil bila dibandingkan dengan jumlah di negara penerima lainnya di kawasan seperti Malaysia, Singapura, Hong Kong dan Thailand. Asumsinya terdapat sejumlah faktor yang menghalangi terwujudnya dampak maksimum dari faktor pendorong dan penarik ini. Tulisan ini menganalisa faktor-faktor penghambat tersebut, terutama terkait dengan tingginya persyaratan yang ditetapkan oleh Korea Selatan dan keterbatasan kemampuan untuk memenuhi persyaratan ini dari sisi Indonesia. Pemahaman tentang faktor-faktor penghambat ini akan dapat berkontribusi bagi upaya meningkatkan jumlah pekerja Indonesia di Korea Selatan, yang dapat dianggap sebagai negara yang cukup aman untuk tempat bekerja.

Kata Kunci: Migrasi tenaga kerja, faktor tarik ulur, program G to G, Pekerja Indonesia.
\end{abstract}

\begin{abstract}
An analysis of why people migrate to work in another country is commonly conducted through a listing and description of the push and pull factors, with low income and high unemployment being the push factors and high income and low unemployment being the pull factors. It can be used to explain in general the reasons for temporary labour migration but not to explain why people choose to migrate to a certain country, instead of the others. This is the case of South Korea and Indonesia. There is still a number of Indonesian workers seeking for employment abroad, and there is also a high demand for foreign workers in South Korea. However, the number of Indonesians working in South Korea can still be considered small if compared to the numbers of Indonesians working in other countries in the region, such as Malaysia, Singapore, Hong Kong and Taiwan. The assumption is that there are factors that hinder maximum impacts of this push and pull factors. This paper looked into these hindering factors which are mainly related to the high requirements from the South Korea side and the inability to fulfill the requirements from the Indonesia side. An understanding of these hindering factors may contribute to the efforts of increasing the number of Indonesians working in South Korea, which is considered as a reasonably safe country to work in. Keywords: Labour migration, push and pull factor, G to G programme, Indonesian labour.
\end{abstract}

\section{INTRODUCTION}

Labour migration is one of the forms of international migration, which according to Martin (2013) is motivated by demographic and economic inequalities, as well as communication, transportation and human rights revolutions (Martin, 2013). Martin pointed out how the high demo-

graphic growth tends to occur in 170 poorer countries, while the demography in wealthier countries tends to grow slower. Economically, wealth is more concentrated in countries with smaller population. This is believed to be the reasons for people to work abroad where wages are higher, 
particularly the young ones.

As argued by Sang-Chul Park (2016), over the past four decades, East Asia has been considered as the fastest growing region in the world, which was started by the industrialization, nation building, and post-war reconstruction process in Japan at the beginning of the 20th century (Park, 2016, pp. 1-24), which made Japan the first tier country. Later on, Hong Kong, Singapore, South Korea, and Taiwan, as the second tier nations, showed a rapid development during the 1970s and 1980s, which made them known as the newly industrialized economies (NIEs). The Philippines, Malaysia, and Thailand are considered as the third tier, and China, Indonesia and Vietnam are categorized as the fourth tier (Park, 2016, pp. 1-24). By this categorization, in accordance to the push and pull factors assumptions, between Indonesia and South Korea, the flow of migrant workers come from the first to the later. Furthermore, in 2016, the Bloomberg Innovation Index reported South Korea as the "world's most innovative economy, surpassing Germany (second) and Sweden (third)" (Putra, 2017). Naturally, it makes South Korea more attractive destination for migrant workers, including those from Indonesia.

The rapid economic development which happened in Asia contributed to the shift of trend of migration within the region. According to Yazid, while earlier research of migration in Asia was more focused on internal permanent migration, particularly migration from rural to urban areas (Yazid, 2013, p. 73), since the 1980s, the trend was shifted to temporary labour migration between Asian countries (Yamanaka and Piper in Sylvia Yazid, 2013, p. 55). Yazid also argued that the migration goals have "shifted more towards economic purposes, where more people migrate to seek employment." (Yazid, 2013, p. 56) which is commonly known as labor migration.

The International Labour Organization (ILO) defines labour migration as "the movement of people from one country to another for the purpose of employment" (IOM, n.d.) or a "cross-border movement for purposes of employment in a foreign country (International Organization for Migration, n.d.)." In line with these definitions, the International Convention on the Protection of the Rights of All Migrant Workers and Members of Their Families Ar- ticle 2 (1) defines migrant worker as "a person who is to be engaged, is engaged or has been engaged in a remunerated activity in a State of which he or she is not a national (OHCHR, 2005)." Similarly, Law No. 39/2004 in Indonesia defines Indonesian migrant worker or Tenaga Kerja Indonesia (TKI) as an Indonesian citizen who is eligible or fulfill the requirements to work abroad in a work relationship or employment in a certain period of time and receive wages. Since more and more countries are involved in labour migration and there are already shifts from what considered to be the traditional choices of destination countries, it is crucial to understand the factors that affects the flow of migration from one particular country to another. This paper initially discusses the push and pull factors that influence labour migration from Indonesia to South Korea. However, the main aim of this paper to highlight other factors which can explain why despite the attractive scheme of labour migration to South Korea, the number of Indonesian migrant workers in South Korea remains low compared to that of other destination countries in the region. It is believed that these factors have been hindering the possibility of a significant increase of labour migration from Indonesia to South Korea. As this is a preliminary research on the topic, it relies more on the data gathered through a desk study approach.

\section{ANALYSIS}

UNDERSTANDING THE PUSH AND PULL FACTORS BETWEEN INDONESIA AND SOUTH KOREA

In discussing the factors influencing both economic and non-economic migration, Martin and Widgren categorized the factors into demand-pull, supply-push, and network/other (P. Martin and J. Widgren in Martin and Zürcher, 2008). Just like other analysis of push and pull factors, they see labor recruitment in destination country as the demand-pull factor, while unemployment or underemployment and low wages in sending countries as the supply push factors. They added job and wage information flow as other contributing factors. South Korea actually has potential employment offers and Indonesian workers who have worked in South Korea experienced relatively safe and beneficial migration. However, it has been a challenging task to fulfill the quota for Indonesian workers. In 
short, this paper aims to provoke more questions directed toward why people choose one country instead of the other, even when the later offers more compared to the first one.

As argued by Yazid (Yazid, 2013, p. 73), the main push factor in Indonesia is the inability of domestic job market to accommodate the growing labour force. According the Central Bureau of Statistics Indonesia, by February 2017, the Indonesian labour force has reached the number 131.55 million (Central Bureau of Statistics Indonesia, n.d.). More than five percent of them are categorized as unemployed, which comes to around seven million people. This number has not covered those who are in between jobs, or working part time. Another factor that Yazid pointed out is the importance of remittance brought by migrant workers to the national income. In 2016, the remittance brought by Indonesian migrant workers reached the number 120 trillion Rupiahs, or more than 9 billion US Dollars.

As for the pull factors in South Korea, besides its status as one of the NIEs and the fact that its economy is stronger than Indonesia, in terms of labour migration, South Korea offers relatively higher income and more guarantee towards the rights of the migrant workers. As indicated by a number of sources, 1 Indonesians working in South Korea can receive from 10 to more than 20 million Rupiahs of wages. According to the National Agency for the Placement and Protection of Indonesian Overseas Workers or Badan Nasional Penempatan dan Perlindungan Tenaga Kerja Indonesia (BNP2TKI), the interest to work in South Korea is very high, 30-33 thousand people each year. In 2017, the number of applicants reaches 31.803 migrant worker candidates (Suwarto, 2017). This high interest is mainly based on the high offered wages which will be further be added with overtime and other benefits (BNP2TKI, 2016; Fikri, 2017; Hardum, 2014). In addition, the Indonesian migrant workers who worked in South Korea may obtain the pension fund up to 30-50 million Rupiahs (US\$ 2800-4800) (Fikri, 2017).

Another, supposed to be, pull factor in South Korea is the guarantee that they give for the rights of the migrant workers, which is highly needed by Indonesian migrant workers. Indonesia is considered to be a "major supply country of migrant workers, mostly confined in low-skilled and low-paid job sectors (domestic work, fishery, planta- tion) (IOM, Factsheet, n.d.)." Also, not all Indonesians migrate through official channels and frequently become undocumented during their time abroad. With this general condition, abuse, exploitation, isolation, underpaid, overworked, mistreated, forced labour, human trafficking, violence, and even death row are prone to be experienced by the migrant workers (Malay \& Axelrod, 2015; Coca, 2016). Thus, protection becomes increasingly significant and continuously sought. At the beginning of his presidency, Indonesia's current president, Joko Widodo, expressed his high concerned with the safety of Indonesian migrant workers abroad, he stated that "The practice of Indonesian women going overseas to work as housemaids must stop immediately. We should have pride and dignity (Whiteman, 2017)." This concern is reflected in Indonesia's Medium Term Development Plan (RPJMN) 2015-2019, in which protection of Indonesians abroad become one of the main priorities (International Labour Organization, n.d.). To do so, the government is focusing on "the realization of recruitment and placement mechanisms that protect migrant workers" and the increase of "Indonesian migrant workers who have the skills and expertise that are inline with market needs." This indicates a strong policy effort to provide better protection through the upgrading of the skills of the migrant workers. The placement scheme made with the government of South Korea is inline with this mission of providing better protection for Indonesian migrant workers.

South Korea is one of the few destination countries that guarantee the rights and protections of migrant workers through its national policies. The migrant workers in South Korea come from 90 different nationalities, among them are migrant workers from Bangladesh, China, Indonesia, Mongolia, Nepal, Pakistan, the Philippines, Sri Lanka and Vietnam (OHCHR, n.d.). The largest group of migrant workers in South Korea are Korean-Chinese migrant workers with 33,546 people $(54,1 \%)$, followed by migrant workers coming from China with 62,058 people (45\%), while the second largest group are migrant workers from Vietnam (7.4\%), Bangladesh (6.9\%), The Philippines (6.5\%), and Indonesia (6.1\%) (OHCHR, n.d.). South Korea used to be a labor exporting country until the late 1980s. It has changed to be a labor importing country circa 
Figure 1. The placement of Indonesian workers in South Korea through G to G programme (2011-2016)

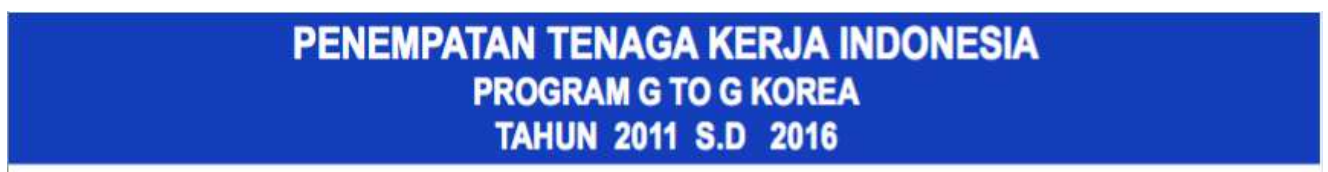

\begin{tabular}{|c|c|c|}
\hline NO & TAHUN & JUMLAH TKI \\
\hline 1 & 2011 & 6.325 \\
\hline 2 & 2012 & 6.410 \\
\hline 3 & 2013 & 9.441 \\
\hline 4 & 2014 & 7.382 \\
\hline 5 & 2015 & 5.505 \\
\hline 6 & 2016 & 5.662 \\
\hline \multicolumn{2}{|c|}{ TOTAL } & 40.725 \\
\hline
\end{tabular}

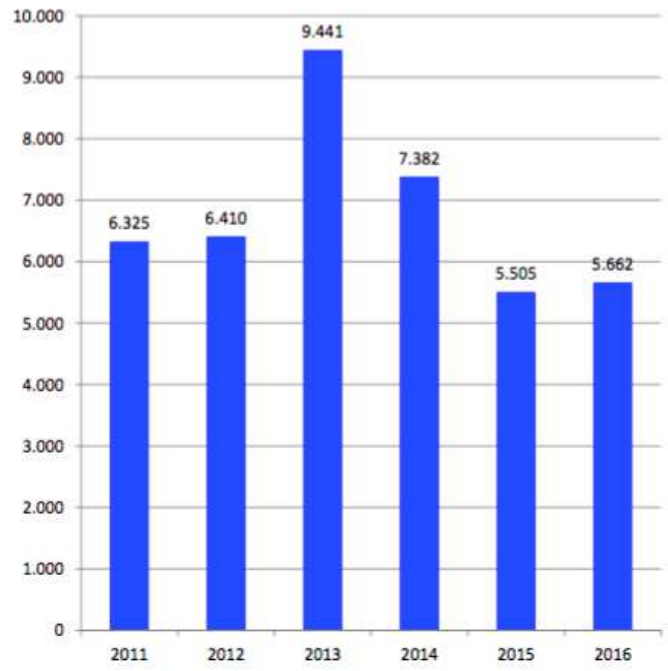

Source: Data Penempatan dan Perlindungan Tenaga Kerja Indonesia Tahun 2016. Pusat Penelitian dan Pengembangan Informasi. Badan Nasional Penempatan dan Perlindungan Tenaga Kerja Indonesia.

1987 when domestic workers from the Philippines were employed in Seoul (OHCHR, n.d.). The rapid economic growth in South Korea led to the raise of Korean workers' income and expectations. "The demand for manual and unskilled workers in small and medium sized companies, known as '3D' (dirty, dangerous, and difficult) jobs are filled by low-paid migrant workers (OHCHR, n.d.)." However, by the end of $2002,80 \%$ of 290,000 migrant workers in South Korea are considered as irregular migrant workers, only when the Employment Permit System (EPS) are enforced, the number declines to 189,000 irregular migrant workers (nearly $52 \%$ of the total) (OHCHR, n.d.). At present, the demand for foreign workers is more focused on skilled ones.

The EPS Act entered into force in August 2004, with the intention to "give migrant workers legal status and to put an end to human rights violations against them (OHCHR, n.d.)." This move made South Korea "the first labor importing country in Asia to attempt to protect the rights of migrant workers through legislation." Under the provision of this act, in August 2004, South Korea signed bilateral agreements with six countries, namely the Philip- pines, Sri Lanka, Mongolia, Indonesia, Thailand and Vietnam. This act legally allows South Korean employers to seek for foreign workers that can be contracted for one to three years if they cannot find Korean worker to fill the vacancy. Furthermore, it protects foreign workers from acts of discrimination.

Following this bilateral agreement, in 2006, the government of Indonesia, conducted Government to Government ( $G$ to $G$ ) program for Indonesian migrant workers to South Korea through Direktorat Penempatan dan Perlindungan Tenaga Kerja Luar Negeri (PPTKLN) which is a directorate under the department of Manpower and Transmigration. The program was later assigned to BNP2TKI when it was established in 2007 (BNP2TKI, 2011). This $G$ to $G$ arrangement seems to make the migration process more organized. The website of BNP2TKI provides information on selection process, requirement, job availability and even to the small details of what to bring and where to get assistances.

With the high wage and better guarantee for rights and protection, South Korea should have been a more attractive destination for working abroad for Indonesians. In 
many occasions, South Korea is mentioned among the top destination countries of Indonesian migrant workers. However, as mentioned above, the number of Indonesian workers in South Korea is still small compared to the number of Indonesian workers in other countries in the region where South Korea is at the sixth place.2 Based on the abovementioned table, the number of Indonesian migrant workers sent to South Korea has gone through a fluctuation. The highest number of Indonesian migrant workers sent to South Korea was in 2013 with a total of $9.441 \mathrm{mi}-$ grant workers. However, the number decreased to 7.382 migrant workers in the following year, and decreased to 5.505 migrant workers in 2015. The number slightly increased to 5.662 migrant workers in 2016. The significant increase in 2013 may be correlated with two policy moves. In 2013 there was a renewal of Memorandum of Understanding between the Ministry of Manpower and Transmigration, Indonesia and the Ministry of Employment and Labor, South Korea on the placement of Indonesian Workers in South Korea. The second move was an initiatitive to give workers who have the potential to become overstayers an oppportunity to work in South Korea again, as long as they go back to Indonesia and join the Employment Permit System - Test of Proficiency in Korean Computer Based Test. It is important to look into the factors that cause this fluctuation and it also needs to be noted that this annual number is only filling less than 50 percent of the quota given by South Korea.3 Therefore, there must be factors that hinder a significant increase in the number of labour migration from Indonesia to South Korea, that prevent the maximum impacts of both the push and pull factors.

From the Indonesian side, the hindering factors may include personal social and cultural view and preferences, and lack of skills from the migrant worker candidates. As argued by Martin and Zürcher, "most migration in Asia involves workers moving from one country to another in the region for temporary employment (Martin and Gottfried, 2008, p. 14)." There's also a trend of migration where Asian workers migrate to a country closer to home, with Indonesian workers prefer to migrate to Malaysia or Singapore. This choice is usually made because Malaysia and Singapore is considered closer both in terms of distance and culture. The shared Malay identity is often con- sidered as a 'safety blanket' for Indonesian migrant worker candidates, especially when they put language and religion as part of the considerations. As highlighted by Yazid (2013), Malaysia is considered as a 'friendlier' place to work because it is assumed that adaptation will be easier given the similar culture and language (Yazid, 2013, p. 73). In reality, this assumption is not entirely true. Many abuses were triggered by misunderstandings from different meaning of a certain word. One might assume that with the intense and frequent exposure of Korean cultures through the Korean wave to Indonesia, more Indonesians will be familiar with South Korea. However, the familiarity is not enough for Indonesian to consider South Koreans as their 'saudara serumpun' or one rooted relatives. Also, language and distance are still considered as hindering factors.

The factor can be considered as hindering from the South Korea side is the limited entry point and high requirement set for foreign workers. Based on the agreement between the two countries, the sending of Indonesian workers to South Korea can only be conducted through the Government to Government ( $G$ to $G$ program) which is fully operated by the government institutions, in this case, BNP2TKI from Indonesian side, and the Human Resources Development Service of Korea (HRD Korea) from the Korean side. As stated by BNP2TKI, the placements of Indonesian migrant workers to South Korea are only based on the government program, not by any private sectors program and assistances (BNP2TKI, 2017). The next hindering factor is the high requirements and qualifications demanded by South Korea. BNP2TKI stated that according to the MoU between the government of Indonesia and the government of South Korea, all applicants who want to work in South Korea have to follow the mechanism of Employment Permit System (EPS), or known as model rekruitmen Sistem Poin, which is conducted by the Human Resources Development Service of Korea (HRD Korea). (BNP2TKI, Pengumuman dan Pra Pendaftaran Program G to G ke Korea Paper Based Test Sektor Manufaktur Dengan Sistem Poin Tahun 2017, 2017) This system requires candidates to go through tests, meet certain qualification which has to be proven by a number of certifications, and provide a number of documents. Even for sectors like fishery which in Indonesia might consid- 
Graphic 2. Factors influencing labour migration from Indonesia to South Korea

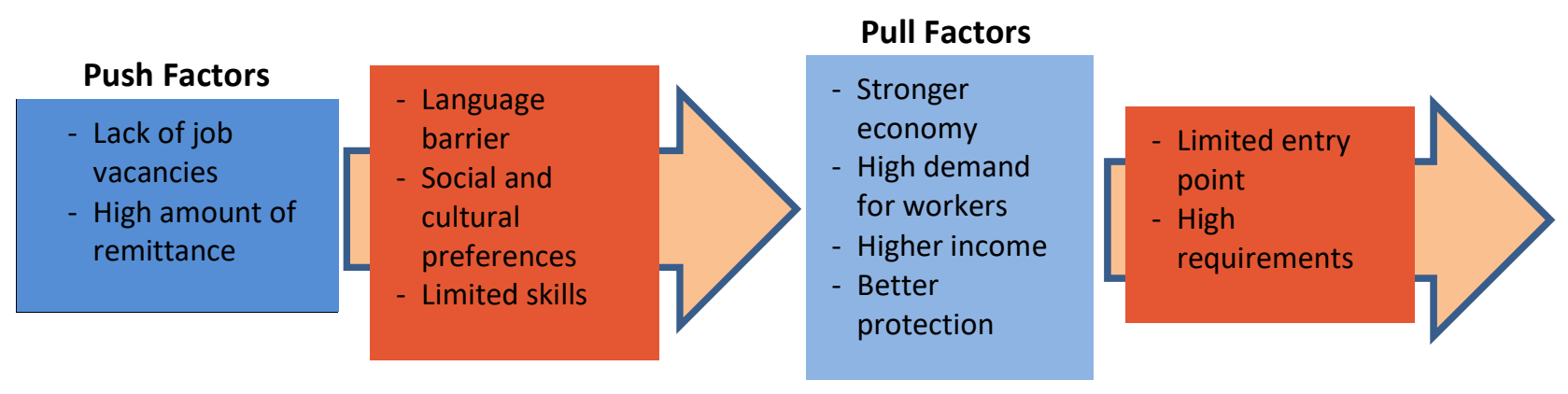

Source: constructed by author

ered more as a physical job, the applicants are expected to pass a language test and a competency test, which is graded based on the applicant's experience, vocational trainings, courses, Basic Safety Training, and other certificates that certify their abilities (BNP2TKI, 2016). Out of more than 30 thousand that apply each year, only around 6,500 pass the tests (BNP2TKI, Lembaga Kursus Tidak Bisa Menjamin Penempatan Calon TKI ke Korea, 2016). Also, the candidates have to prepare some money to guarantee their wellbeing including an amount enough to cover a Korea-Indonesia ticket to be used in the case of deportation.4 Limited mastery of language might be a barrier in many destination countries. However, in migrating to Korea, the language mastery becomes one of the major challenges because it is set as a part of employment requirements. Unfortunately, the majority of Indonesians who want to migrate for work cannot fulfill or not patient enough to prepare these requirements. Therefore, they tend to choose countries with lower requirements. The government of South Korea is also quite strict in implementing its policy on foreign workers. There have been instances when the government of South Korea put an end to improper recruitment practices. In June 2005, for example, after discovering "improper job-brokering activities in Indonesia," the South Korean government suspended the recruitment of Indonesian workers under the EPS (United Nations High Commissioner for Human Rights, 2017).

The above discussion has emphasized the importance of looking at factors other than those considered as the conventional push and pull factors. The arguments can be illustrated as follows: (see picture)
The factors in the blue boxes are the push and pull factors while the factors in the orange boxes are the factors that prevent the maximum impacts of the push and pull factors. It is believed that efforts directed toward overcoming these factors may allow the number of labour migration from Indonesia to South Korea to increase.

\section{IMPROVING SKILLS THROUGH VOCATIONAL EDUCATION}

The discussion above has shown that one of the main challenges is the limited skills possessed by Indonesian migrant worker candidates. As a response, the Indonesian government has made efforts to improve the skills of Indonesian workforce. One of the initiatives is to strengthen the vocational education. As an example, in 2015, the head of BNP2TKI, Nusron Wahid, stated that the Indonesian migrant workers are obliged to attend the intensive training and education program, known as 'SMK Mini' (Armenia, 2015). This initiative has been conducted in East Java, with 300 local points and 90 migrant workers candidate in each point (Armenia, 2015). The program focuses on the skill training with the duration of approximately six until eight months (Armenia, 2015). At the beginning of 2017, this effort has been strengthened with the establishment of "Peraturan Menteri Perindustrian Nomor 3 tahun 2017 tentang Pedoman Pembinaan dan Pengembangan Sekolah Menengah Kejuruan Berbasis Kompetensi yang Link and Match dengan Industri (Moneter.co.id, 2017)." The head of Indonesian Ministry of Industry, Airlangga Hartanto, explained that this regulation will be used as a guideline for the vocational schools to give education materials which has the 'link and match' with industry 
(Moneter.co.id, 2017). The government has targeted the number of participants in this program to reach one million people in 2019, by involving 200 vocational school in Indonesia (Moneter.co.id, 2017). The vocational school also have to create the curriculum which goes in accordance with the Standar Kompetensi Kerja Nasional Indonesia (SKKNI) as well as the international standard (Moneter.co.id, 2017).

These efforts can be the starting point to have more skilled Indonesian migrant workers which will be beneficial not only to Indonesia as the sending country, but also to the receiving country that demands more and more skilled migrant workers. It could also increase the chance for Indonesian migrant workers to be accepted in South Korea since Indonesian workers have already gained quite a good reputation in South Korea for having strong determination and high seriousness at work (BNP2TKI, 2.049 Orang Calon TKI Rebut Peluang Sektor Perikanan di Korea, 2016). A combination of provision of vocational education which is specifically designed to provide skills needed to work in the sectors available in receiving countries and the cooperative, hardworking and determinant characteristics of Indonesian workers, will further increase the reputation of Indonesian workers, not only in South Korea, but also in other receiving countries.

\section{CONCLUSION}

An effort to understand why people leave their countries to work in foreign countries is commonly supported by an analysis of the push and pull factors. However, the case of Indonesia-South Korea shows that there is more to the push and pull factors. If seen individually, each country has the 'required' push and pull factors that should have led to higher numbers of Indonesian workers working in South Korea. There is still a high number of Indonesian seeking for jobs abroad and South Korea is offering safe employment with high wages. However, apparently, there are factors that hold back these push and pull factors. As discussed in this paper, if the aim is to provide safe and beneficial migration for Indonesians, the migration scheme to South Korea seems to be one of the logical choices. However, this preferable mechanism of labour migration comes with a number of requirements which unfortunately can only be met by limited number of Indonesians. South Korea limit the influx of labour migration to those organized by the government with set requirements in terms of skills and competencies.

The government of Indonesia is moving towards reducing the sending of unskilled workers abroad and increasing the sending of skilled workers in the effort of providing better guarantee of the safety of Indonesians abroad. The existing $G$ to $G$ agreement between Indonesia and South Korean government should be sustained and developed further since South Korea already has an act which provide a protecting mechanism for foreign workers. Therefore, the government's effort to arrange a safer and beneficial mechanism for labour migration need to be supported by the strengthening of the labour force through skills and competencies improvements.

This paper was written based on data gathered through a desk-study. Obviously to provide a more comprehensive answer to the question why labour migration from Indonesia to South Korea remains lower than other major destination countries, a more in-depth research is required, which can be the next proposed research activity.

\section{ACKNOWLEDGEMENT}

The author would like to acknowledge the assistance given by Agatha Lydia Natania in researching for this paper.

\section{END NOTE}

1 Despite a number of cases of unpaid wages, the media has highlighted that Indonesian workers tend to receive high wages in South Korea. In 2013, the minimum wage in South Korea was one million won or approximately US\$900, the amount could be higher if added by overtime. The Indonesian migrant workers can get up to two million won (20 million Rupiahs or \$US1800) (Joko Sedayu, Nur Alfiyah, "Indonesia to Send 4,000 Migrant Workers to Korea," Tempo.co, May 8, 2013, accessed May 13, 2017, https://m.tempo.co/read/news/ 2013/05/08/055478814/indonesia-to-send-4-000-migrantworkers-to-korea). Based on interview conducted by Kartikasari in 2013, the Indonesian migrant workers might earn 1 million 1.5 million won or US\$800-1300, depends on the overtime. (Nidya Kartikasari, "Effects of Labor Immigration Policies on Indonesian Migrant Workers in Japan and South Korea." National Graduate Institute for Policy Studies. 2013. Accessed May 10, 2017, http://www.grips.ac.jp/cms/wp-content/ uploads/2014/04/fulltextdoc08010.pdf). In 2016, Center for 
Indonesian Policy Studies highlighted that South Korea is considered as one of the favorite destination for Indonesian migrant workers because of the higher income, the amount is still higher than the income in Hong Kong and Taiwan. Indonesian migrant workers can get approximately 10-20 million Rupiahs (US\$800-1800) per month. ("Indonesia, Korea, and Migrant Workers," Center for Indonesian Policy Studies, January 18, 2016, accessed May 13, 2017, http://cipsindonesia.org/en/indonesia-korea-and-migrant-workers/). In 2016, BNP2TKI reported that the Indonesian migrant workers can get approximately 11-15 million Rupiahs every month. (BNP2TKI, "Lepas 146 TKI ke Korea, Tahun Ini Masih Tersedia 1700 Lowongan," July 16, 2016, accessed May 13, 2017, http:/ /www.bnp2tki.go.id/read/11463/Lepas-146-TKI-ke-KoreaTahun-Ini-Masih-Tersedia-1700-Lowongan). BNP2TKI also stated that the minimum wage for Indonesian migrant workers in the sector of fishery is 1.2 billion won (13 million Rupiahs) with the 'take home pay' might reach 20 million Rupiahs every month. (BNP2TKI, "2.049 Orang Calon TKI Rebut Peluang Sektor Perikanan di Korea," Oktober 23, 2016, accessed May 13, 2017, http://www.bnp2tki.go.id/read/11757/2.049-OrangCalon-TKI-Rebut-Peluang-Sektor-Perikanan-di-Korea).

2 According to BNP2TKI, in 2016, 87.616 Indonesian migrant workers were sent to Malaysia, 77.087 were sent to Taiwan, 13.538 were sent to Saudi Arabia, 14.434 were sent to Hong Kong, 17.700 were sent to Singapore, 8.152 were sent to Brunei Darussalam, while only 5.912 were sent to South Korea. BNP2TKI, "Data Penempatan dan Perlindungan Tenaga Kerja Indonesia Tahun 2016," Pusat Penelitian dan Pengembangan Informasi, accessed May 13, 2017, http://www.bnp2tki.go.id/ uploads/data/data_08-02-2017_111324_DataP2TKI tahun 2016.pdf.

3 In 2012, South Korea needs 10,500 skilled and semi-skilled workers from Indonesia. "South Korea needs 10,500 Indonesian workers," Antaranews.com, July 27, 2012, accessed May 10, 2017, http://www.antaranews.com/en/news/83651/southkorea-needs-10500-indonesian-workers. In average, Indonesia get a quota of 9,000 migrant workers per year. Embassy of the Republic of Indonesia, Seoul, Republic of Korea, "Bilateral Relations," accessed May 16, 2017, http://kbriseoul.kr/kbriseoul/ index.php/en/relations.

4 Compared to the money that Indonesian migrant candidates have to 'borrow' from their agents or middlemen to cover their migration expenses, this required amount of money to migrate to Korea is still relatively low. However, it has to be provided by the candidates themselves while in other cases of borrowed money, the agents and middlemen will deduct the debt from the migrant workers' monthly wages.

\section{REFERENCES}

"Ciptakan TKI Terampil, Kemenperin Terbitkan Permen Nomor 3/ 2017." Moneter.co.id, February 13, 2017. Accessed May 15, 2017. http://moneter.co.id/10442/ciptakan-tki-terampilkemenperin-terbitkan-permen-nomor-3-2017.

"Indonesia, Korea, and Migrant Workers," Center for Indonesian
Policy Studies, January 18, 2016. Accessed May 13, 2017. http://cips-indonesia.org/en/indonesia-korea-and-migrantworkers/.

"South Korea needs 10,500 Indonesian workers." Antaranews.com, July 27, 2012. Accessed May 10, 2017. http:// www.antaranews.com/en/news/83651/south-korea-needs10500-indonesian-workers.

Armenia, Resty. "BNP2TKI: Calon TKI akan Digembleng di SMK Mini." CNN Indonesia, May 15, 2015. Accessed May 15, 2017. http://www.cnnindonesia.com/nasional/20150515141137-2053426/bnp2tki-calon-tki-akan-digembleng-di-smk-mini/.

BNP2TKI. "2.049 Orang Calon TKI Rebut Peluang Sektor Perikanan di Korea." Oktober 23, 2016. Accessed May 13, 2017. http:// www.bnp2tki.go.id/read/11757/2.049-Orang-Calon-TKI-RebutPeluang-Sektor-Perikanan-di-Korea.

BNP2TKI. "Data Penempatan dan Perlindungan Tenaga Kerja Indonesia Tahun 2016." Pusat Penelitian dan Pengembangan Informasi. Accessed May 13, 2017. http://www.bnp2tki.go.id/ uploads/data/data_08-02-2017_111324_DataP2TKI_tahun_2016.pdf.

BNP2TKI. "Lembaga Kursus Tidak Bisa Menjamin Penempatan Calon TKI ke Korea." March 7, 2016. Accessed May 8, 2017. http:// www.bnp2tki.go.id/read/11112/-Lembaga-Kursus-Tidak-BisaMenjamin-Penempatan-Calon-TKI-ke-Korea.html.

BNP2TKI. "Lepas 146 TKI ke Korea, Tahun Ini Masih Tersedia 1700 Lowongan." July 16, 2016. Accessed May 13, 2017. http:// www.bnp2tki.go.id/read/1 1463/Lepas-146-TKI-ke-Korea-TahunIni-Masih-Tersedia-1700-Lowongan.

BNP2TKI. "Pengumuman dan Pra Pendaftaran Program G to G ke Korea Paper Based Test Sektor Manufaktur Dengan Sistem Poin Tahun 2017." Accessed May 10, 2017. http:// g2g.bnp2tki.go.id.

BNP2TKI. "Sejarah Penempatan TKI Hingga BNP2TKI." Februari 27, 2011. Accessed May 8, 2017. http://www.bnp2tki.go.id/frame/ 9003/Sejarah-Penempatan-TKI-Hingga-BNP2TKI.

Central Bureau of Statistics Indonesia Official Website. Accessed May 11, 2017, https://www.bps.go.id/index.php/brs/1376.

Coca, Nithin. "A slow road to end abuse of Indonesia's migrant workers." Southeast Asia Globe, June 24, 2017. Accessed May 8, 2017. http://sea-globe.com/19589-2-migrant-workersindonesia/.

Embassy of the Republic of Indonesia, Seoul, Republic of Korea, "Bilateral Relations," accessed May 16, 2017, http://kbriseoul.kr/ kbriseoul/index.php/en/relations.

Fikri, Ahmad. "Asyiikk, TKI di Korea Selatan Dapat Uang Pensiun Rp 30-50 Juta." Tempo.co, April 27, 2017. Accessed May 15, 2017. https://bisnis.tempo.co/read/news/2017/04/27/ 090870197/asyiikk-tki-di-korea-selatan-dapat-uang-pensiun-rp30-50-juta.

Fikri, Ahmad. "Karena Gaji, Korea Selatan jadi Tujuan Favorit Calon TKI," Tempo.co, April 27, 2017. Accessed May 15, 2017. https:/ /bisnis.tempo.co/read/news/2017/04/27/090870204/karenagaji-korea-selatan-jadi-tujuan-favorit-calon-tki.

Hardum, Edi. "'Indonesian Migrant Workers Best': South Korea." Jakarta Globe, February 18, 2014. Accessed May 15, 2017. http://jakartaglobe.id/news/indonesian-migrant-workers-best- 
south-korea/.

International Labour Organization. "Indonesia: Decent work for Indonesian migrant workers." Asia-Pacific Decent Work Decade. Accessed May 8, 2017, http://www.refworld.org/pdfid/ $557 \mathrm{fe} 1 \mathrm{bf} 4$.pdf.

International Organization for Migration Official Website. "Labour Migration." Accessed May 8, 2017. https://www.iom.int/labourmigration.

International Organization for Migration. "Labour Migration." Factsheet. Accessed May 8, 2017. https://indonesia.iom.int/ sites/default/files/Factsheet\%20-\%20Labour\%20Migration.pdf.

International Organization for Migration. "Migration and Labour." Essentials of Migration Management Volume 2: Developing Migration Policy. Accessed May 8, 2017. http://www.rcmvs.org/ documentos/IOM_EMM/v2N2S06_CM.pdf.

Kartikasari, Nidya. "Effects of Labor Immigration Policies on Indonesian Migrant Workers in Japan and South Korea." National Graduate Institute for Policy Studies. 2013. Accessed May 10, 2017. http://www.grips.ac.jp/cms/wp-content/ uploads/2014/04/fulltextdoc08010.pdf.

Martin, Philip and Gottfried Zürcher. "Managing Migration: The Global Challenge." Popular Bulletin 63, no. 1, (2008):14. Accessed May 2, 2017. http://www.albany.edu/ yhuang/ PRB_ManagingMigrationTheGlobalChallenge.pdf.

Martin, Philip, and Jonas Widgren. "International Migration: Facing the Challenge." Population Bulletin 57, no.1 (2002) in Philip Martin and Gottfried Zürcher. "Managing Migration: The Global Challenge." Popular Bulletin 63, no. 1 (2008): 4. Accessed May 8, 2017. http://www.albany.edu/ yhuang/ PRB_ManagingMigrationTheGlobalChallenge.pdf.

Martin, Philip. "The Global Challenge of Managing Migration." Population Bulletin 68, no.2 (2013): 3. Accessed May 2, 2017. http://www.prb.org/pdf13/global-migration.pdf.

Michael, Malay and Nicolas Axelrod. "Indonesia's Migrant Workers: Dreams and Tears." The Diplomat, March 16, 2015. Accessed May 8, 2017. http://thediplomat.com/2015/03/indonesiasmigrant-workers-dreams-and-tears/.

Office of the United Nations High Commissioner for Human Rights. "The International Convention on Migrant Workers and its Committee." Fact Sheet No. 24 (Rev1) 2005. Accessed May 8, 2017. http://www.ohchr.org/Documents/Publications/ FactSheet24rev. 1 en.pdf.

Park, Sang-Chul. "East Asian Culture and Economic Miracle: The South Korean Experience." Institutions and Economics 8, no. 1 (2016): 1-24. Accessed May 11, 2017. http://ijie.um.edu.my/ filebank/published_article/9381/ East\%20Asian\%20Culture\%20and\%20Economic\%20Miracle\%20\%20The\%20South\%20Korean\%20Experience.pdf.

Putra, Arif Kelana. "Economy: Learning from South Korea's Experience." The Jakarta Post, March 20, 2017. Accessed May 11, 2017. https://www. pressreader.com/indonesia/the-jakartapost/20170320/281706909498774.

Sedayu, Joko and Nur Alfiyah. "Indonesia to Send 4,000 Migrant Workers to Korea." Tempo.co, May 8, 2013. Accessed May 13, 2017. https://m.tempo.co/read/news/2013/05/08/055478814/ indonesia-to-send-4-000-migrant-workers-to-korea.
Suwarto, Tok. "30.109 Calon TKI ke Korea Ikut tes EPS-TOPIK." Pikiran Rakyat, April 1, 2017. Accessed May 11, 2017. http:// www. pikiran-rakyat.com/nasional/2017/04/01/30109-calon-tkike-korea-ikut-tes-eps-topik-397757.

United Nations High Commissioner for Human Rights (OHCHR). "Republic of Korea (South Korea): 'Migrant workers are also human beings'." Accessed May 3, 2017. http://lib.ohchr.org/ HRBodies/UPR/Documents/Session2/KR/

Al_KOR_UPR_S2_2008anx_Migrantworkersarealsohumanbeings.pdf.

Whiteman, Hilary. "Indonesia maid ban won't work in Mideast, migrant groups say." CNN, May 6, 2017. Accessed May 8, 2017. http://edition.cnn.com/2015/05/06/asia/indonesiamigrant-worker-ban/.

Yamanaka, Keiko and Nicola Piper. "Feminized Migration in East and South-east Asia: Policies, Actions and Empowerment." United Nations Research Institute for Social Development. 2005. Accessed May 16, 2017, http://www.unrisd.org/ 80256B3C005BCCF9/httpNetITFramePDF? ReadForm\&parentu nid $=0$ 6C975DEC6217D4EC125713900 29829A\& parentdoctype $=$ paper\&netitpath $=80256 \mathrm{~B} 3$ C005BCCF9/ (httpAuxPages) /06C975DEC6217D4EC12571390029829A \$file/OP11\%20web.pdf

Yazid, Sylvia. Indonesia's Civil Society in the Age of Democratization: NGO Responses on the Issue of Labor Migration. BadenBaden: Nomos, 2013. 